\title{
Clinical characteristics and association analysis of persistent low-level HBsAg expression in a physical examination population with $\mathrm{HBV}$ infection
}

\author{
YUZHU DAI $^{1,2^{*}}$, FEIHU CHE $^{1 *}$, XIAOXIAO JIANG ${ }^{3 *}$, DAWEI CUI $^{2}$, HUAJUN ZHOU $^{1}$, \\ XUJIAN XU ${ }^{4}$, CHANGGUI SUN ${ }^{1}$ and JUN CHENG ${ }^{1,5,6}$
}

${ }^{1}$ Department of Clinical Laboratory, The 903rd Hospital of The PLA, Hangzhou, Zhejiang 310013;

\begin{abstract}
${ }^{2}$ Department of Laboratory Medicine, Key Laboratory of Clinical In Vitro Diagnostic Techniques of Zhejiang Province, The First Affiliated Hospital, College of Medicine, Zhejiang University, Hangzhou, Zhejiang 310003; ${ }^{3}$ Department of Respiration, The 903rd Hospital of The PLA, Hangzhou, Zhejiang 310013, P.R. China; ${ }^{4}$ Department of Biotechnology, University of Tokyo, Tokyo 1138656, Japan; ${ }^{5}$ Department of Medical Laboratory, Faculty of Graduate Studies, Jiangsu University, Zhenjiang, Jiangsu 212013; ${ }^{6}$ Department of Medical Laboratory, Faculty of Graduate Studies, Bengbu Medical College, Bengbu, Anhui 233000, P.R. China
\end{abstract}

Received January 3, 2019; Accepted August 5, 2019

DOI: $10.3892 / \mathrm{etm} .2019 .8217$

\begin{abstract}
Certain patients with hepatitis B virus (HBV) infection present with persistently low levels of serum hepatitis B surface antigen (HBsAg) and have been indicated to have low rates of HBV nucleic acid replication. To explore the serological and molecular epidemiological characteristics of HBV population with low-level HBsAg in the present study, associated serum markers and virologic genotype detection were performed accordingly. Determination of HBV markers was performed using a chemiluminescence immunoassay from which 2,544 out of 45,256 adults who underwent routine health examination were tested positive for HBsAg. HBV DNA was detected by real-time fluorescent quantitative PCR. The patients were divided into low-level and high-level groups, according to
\end{abstract}

Correspondence to: Professor Jun Cheng, Department of Clinical Laboratory, The 903rd Hospital of The PLA, 14 Lingyin Road, Westlake, Hangzhou, Zhejiang 310013, P.R. China

E-mail: cj1171967@163.com

*Contributed equally

Abbreviations: $\mathrm{HBV}$, hepatitis B virus; $\mathrm{HBsAg}$, hepatitis B surface antigen; APRI, AST-to-platelet ratio; CMIA, chemiluminescence immunoassay; ALB, albumin; ALT, alanine aminotransferase; AST, aspartate aminotransferase; PLT, blood platelets; TBil, total bilirubin; ASC, asymptomatic HBV carriers; $\mathrm{CHB}$, chronic hepatitis B virus infection; anti-HBs, antibody against HBsAg; $\mathrm{HBeAg}$, hepatitis Be antigen; Anti-HBe, antibody against $\mathrm{HBeAg}$; anti-HBc, antibody against hepatitis B core antigen

Key words: physical examination population, hepatitis B virus markers, hepatitis B virus infection, hepatitis B surface antigen, hepatitis B virus DNA their HBsAg levels (cut-off value, $10 \mathrm{IU} / \mathrm{ml}$ ). The prevalence and levels of HBsAg positivity and HBV DNA in patients with HBV infection were analyzed by age, sex, serological pattern and clinical type. The fibrosis status of patients with low-level HBsAg was assessed by determining the aspartate aminotransferase-to-platelet ratio (APRI), and sequencing was employed to determine serotypes and genotypes. HBV-infected patients with low-level HBsAg $(<10 \mathrm{IU} / \mathrm{ml})$ accounted for $15.41 \%$ of the 2,544 HBsAg-positive patients, and the prevalence of HBsAg positivity exhibited a tendency to increase with age. The male-to-female ratio was $\sim 1.9: 1$, and the average age was $54.98 \pm 16.28$ years among HBV-infected patients with low-level HBsAg. The major serological pattern and clinical types were $\mathrm{HBsAg}$ /antibody against hepatitis $\mathrm{Be}$ antigen (anti-HBe)/antibody against hepatitis B core antigen (anti-HBc)-positive (94.90\%) and chronic asymptomatic (ASC) (97.95\%), respectively. HBV DNA exhibited a low-level of replication and the prevalence of HBV DNA positivity assessed by the routine method and by the enrichment method was $27.74 \%$ (97/392) and 45.92\% (180/392), respectively. No significant differences among the age groups were identified in the different HBsAg level groups $(\mathrm{P}>0.05)$. The prevalence of HBV DNA positivity was associated with HBsAg only in patients with serological pattern HBV-M2 (HBsAg/anti-HBe/anti-HBc-positive) in the low-level HBsAg group (odds ratio: 1.30; 95\% CI: 1.15-1.47; P<0.05). The APRI had no association with age, HBsAg, HBV DNA level or liver function index in ASC patients in the low-level HBsAg group $(\mathrm{P}>0.05)$. The prevalence of the serotype adw and genotype B was 85.53 and $89.47 \%$, respectively. Further improvement in the systematic study of populations with low-level HBsAg has important clinical and epidemiological significance for improving the detection of HBV serological markers, elucidating the mechanisms leading to low-level HBsAg, overcoming immune tolerance to eliminate $\mathrm{HBV}$ infection and preventing HBV transmission. 


\section{Introduction}

Hepatitis B surface antigen (HBsAg) is one of the most important pathogen markers and provides direct evidence of hepatitis $\mathrm{B}$ virus (HBV) infection. Detection of low serum HBsAg levels has important clinical and epidemiological significance. Certain patients with $\mathrm{HBV}$ infection have been reported to have low serum HBsAg levels (1-5) with confirmed nucleic acid replication (6-8), a result that poses new challenges for the prevention and treatment of hepatitis B. These phenomena have drawn attention from clinicians, laboratory diagnostic experts, epidemiologists and molecular biologists (9-15).

It is widely accepted that the level of HBsAg and HBV DNA decreases progressively from the immune-tolerant to the low replicative phase. This phenomenon is thought to be associated with anti-viral therapy or the occurrence of complex host-virus interactions during the natural course of $\mathrm{HBV}$ infection $(16,13)$. The clinical outcome of HBV-infected patients with low-level HBsAg is usually more satisfactory $(17,18)$. A retrospective cohort study by Li et al (19) indicated that interferon treatment results in $\mathrm{HBs} \mathrm{Ag}$ loss and seroconversion in inactive $\mathrm{HBsAg}$ carriers with serum HBsAg levels $<100 \mathrm{IU} / \mathrm{ml}$ and undetectable levels of HBV DNA ( $<100 \mathrm{IU} / \mathrm{ml})$. Seto et al $(20)$ reported on the results of a large case-control study regarding the predictability of HBsAg levels three years prior to $\mathrm{HBsAg}$ seroclearance; it was indicated that serum HBsAg $<200 \mathrm{IU} / \mathrm{ml}$ and a $0.5-\log$ reduction in $\mathrm{HBs} \mathrm{Ag}$ were predictive of $\mathrm{HBsAg}$ seroclearance within three years of follow-up. However, the kinetics of $\mathrm{HBsAg}$ levels preceding spontaneous HBsAg seroclearance have not been fully investigated, and there are few reports on the clinical characteristics or association between HBV DNA and HBV markers in populations with low HBsAg levels $(6,7)$. The present study aimed to investigate the clinical features and association of persistent low-level HBsAg in a population of patients with HBV infection who underwent a physical examination. The results have important clinical significance regarding the accumulation of clinical, virological and molecular epidemiological data and the prevention of HBV transmission, particularly in the $\mathrm{HBV}$-infected population with low HBsAg levels.

\section{Materials and methods}

Samplecollection.Priortoenrollment,each participant provided written informed consent to participate in the study. The study was approved by the Medical Ethics Committee of the 117th Hospital of the PLA under protocol no. PLA-117-20160518. A total of 45,256 adults (age range, 18-74 years; mean age: $45.96 \pm 12.98$ years) consisting of 28,959 males (age range, $18-73$ years; mean age, $45.64 \pm 12.77$ years) and 16,297 females (age range, 19-74 years; mean age, 46.45 \pm 13.32 years) received physical examinations at our hospital between June 2014 and June 2016. The chemiluminescence immunoassay (CMIA), an Architect i2000 analyzer (Abbott Core Laboratory) and the matching HBsAg kits (cat. no. 6C36-32) for HBsAg screening were used. Subsequently, HBsAg-positive serum samples from 2,544 subjects with HBV infection were included in the study. The subjects with low-level HBsAg $(<10 \mathrm{IU} / \mathrm{ml})$ received at least three follow-up examinations within 3-12 months (once every three months) to distinguish them from patients in the early stages of HBV infection, those with acute HBV infection, and those who had short-term or transient low HBsAg levels due to being in the recovery stage of the HBsAg/anti-HBs transition. A low HBsAg level in patients with HBV infection was defined as the absence of an HBsAg level $\geq 10 \mathrm{IU} / \mathrm{ml}$ during the entire follow-up period of the study. None of the patients had received any anti-viral drugs or treatment for liver protection, aminotransferase activity reduction or immunomodulation within six months prior to serum collection. The specimens collected were preserved at $-70^{\circ} \mathrm{C}$.

Determination of clinical laboratory parameters. Clinical laboratory and demographic parameters, including age, sex, albumin (ALB), total bilirubin (TBil), alanine aminotransferase (ALT), aspartate aminotransferase (AST), blood platelets (PLT), HBsAg, antibody against HBsAg (anti-HBs), hepatitis Be antigen ( $\mathrm{HBeAg}$ ), antibody against $\mathrm{HBeAg}$ (anti-HBe), antibody against hepatitis $\mathrm{B}$ core antigen (anti-HBc) and $\mathrm{HBV}$ DNA, were determined and recorded at the time of physical examination. The AST-to-platelet ratio (APRI) was calculated. Biochemical tests were performed using an Architect C8000 analyzer (Abbott Core Laboratory), and PLT was determined with an XE2100 blood analyzer (Sysmex). Serum HBV DNA was measured using the StepOne Plus Real-Time PCR System (Applied Biosystems; Thermo Fisher Scientific, Inc.). HBV and other serum markers were measured using the Architect i2000 (Abbott Core Laboratory) and the Maglumi 4000 (Shenzhen New Industries Biomedical Engineering Co., Ltd.) according to the manufacturer's protocol. $\mathrm{HBV}$ DNA $>30 \mathrm{IU} / \mathrm{ml}, \mathrm{HBsAg}$ $>0.05 \mathrm{IU} / \mathrm{ml}$, anti-HBs $>10 \mathrm{mIU} / \mathrm{ml}, \mathrm{HBeAg}>1.0 \mathrm{~S} / \mathrm{CO}$ (defined as sample relative light unit/relative cut-off light unit), anti-HBe $<1.0 \mathrm{~S} / \mathrm{CO}$ or anti-HBc $>1.0 \mathrm{~S} / \mathrm{CO}$ indicated positive results. If the $\mathrm{HBsAg}$ value measured in the Architect i2000 analyzer was $>250 \mathrm{IU} / \mathrm{ml}$, the sample was diluted to the measurable range $(<250 \mathrm{IU} / \mathrm{ml})$ in normal saline.

To verify the accuracy and consistency of the quantitative measurement of HBsAg levels, another CMIA was performed on 100 randomly selected $\mathrm{HBs}$ Ag-positive specimens using a Maglumi 4000 analyzer and the matching HBsAg kits (cat. no. 130210001M). The neutralization test was used to confirm the results indicating low-level HBsAg levels. Confirmation of HBsAg using the neutralization test was performed as follows: First, $100 \mu \mathrm{l}$ of the collected HBsAg-positive serum sample was added to two sample tubes. Subsequently, either $100 \mu 1$ of anti-HBs $(1,000 \mathrm{IU} / \mathrm{ml}$; Acon Biotech; for measurement) or $100 \mu 1$ normal saline (as a control) was added; the samples were mixed well and incubated in a $37^{\circ} \mathrm{C}$ water bath for $30 \mathrm{~min}$, followed by determination of $\mathrm{HBsAg}$ using the CMIA method. If [(control value-measurement value)/control value] $\geq 50 \%$, the original serum was considered HBsAg-positive; otherwise, the original serum was considered to be a false-positive for HBsAg.

Extraction and detection of $H B V D N A$. HBV DNA was extracted from patients' sera using the NP968 nucleic acid extraction system and a nucleic acid extraction kit (TianLong Science and Technology Co., Ltd) with slight modifications to the routine and enrichment methods. In brief, in the routine method, the 96-well plates for HBV DNA extraction were placed in the NP968 nucleic acid extraction system, and $200 \mu \mathrm{l}$ of the serum samples and $20 \mu \mathrm{l}$ of trypsin were added to the 
first column. The magnetic bars were moved from the second column (with immunomagnetic beads) to the first column, followed by lysis at $90^{\circ} \mathrm{C}$ for $15 \mathrm{~min}$. Subsequently, the magnetic bars were moved from the first column wells to the 3rd column and then to the 4th column; the wells in each column were then washed for $2 \min$ at $85^{\circ} \mathrm{C}$. Finally, the magnetic bars were placed into the wells of the fifth column, followed by elution at $85^{\circ} \mathrm{C}$ for $5 \mathrm{~min}$ in an elution volume of $100 \mu \mathrm{l}$. The magnetic bars were removed, and the magnetic beads were discarded. A total of $100 \mu \mathrm{l}$ of eluent (i.e., HBV DNA extract) was collected for real-time quantitative fluorometric detection of HBV DNA, according to the manufacturer's protocol of HBV DNA fluorescence quantitative detection reagent kit [ACON Biotech (Hangzhou) co., Ltd.] and an ABI StepOnePlus ${ }^{\mathrm{TM}}$ real-time PCR system (Applied Biosystems; Thermo Fisher Scientific, Inc.). Additionally, only difference between the enrichment method and routine method was that $500 \mu \mathrm{l}$ serum samples and $50 \mu \mathrm{l}$ trypsin were added to the first column in the first stage (Slight modifications). The remaining HBV DNA extract was stored at $-70^{\circ} \mathrm{C}$. In the assessment of the results, levels of $\geq 30 \mathrm{IU} / \mathrm{ml}$ were considered HBV DNA-positive. In addition, HBV DNA was extracted from the low-level HBsAg group using the enrichment method. The enrichment method utilized $500 \mu \mathrm{l}$ of the serum samples and $50 \mu \mathrm{l}$ of trypsin; the remaining steps were identical to those of the routine method.

Sequencing of $H B V$ gene $S$. The HBV gene $\mathrm{S}$ was examined in all 97 cases in the low-level HBsAg group and in 100 randomly selected cases from the high-level HBsAg group, the members of which were positive for HBV DNA by the routine method. The HBV gene $\mathrm{S}$ was amplified using the nested PCR method as described in the literature (21). The positive PCR product was recovered, purified and sent to Sangon Biotech Co., Ltd. for sequencing. The primers used for amplification included a pair of outer primers for amplification, including forward, 5'-ACCWTATWCYTGGGAACA A-3', nucleotide (nt) positions 2,819-2,837; and reverse, 5'-TCA GCAAAYACTYGGCA-3', nt 1,190-1,174 and two pairs of inner primers, Ia forward, 5'ACCWTATWCYTGGGAACA A-3', nt 2,819-2,837; and reverse, 5'-GAYGAYGGGATGGGA ATACA-3', nt 617-598 and Ib forward, 5'-GACTYGTGGTGG ACTTCTC-3', nt: 251-269; and reverse, 5'-TCAGCAAAY ACTYGGCA-3', nt 1,190-1,174. The PCR amplification reaction mixture contained $5 \mu 15 \mathrm{X}$ KAPA2G buffer A, $5 \mu 15 \mathrm{X}$ KAPA enhancer, $0.1 \mu 1$ of KAPA2G RobustHotStart DNA polymerase, $0.5 \mu \mathrm{l}$ of $10 \mu \mathrm{M}$ dNTP Mix (TaKaRa Bio, Inc.), $1 \mu \mathrm{l}$ of a $10 \mathrm{M}$ solution of each primer, $3 \mu \mathrm{l}$ DNA template and water for PCR to fill up to a final volume of $25 \mu \mathrm{l}$ in each $25 \mu \mathrm{l}$ reaction tube. The first round of amplification included: Pre-denaturation at $95^{\circ} \mathrm{C}$ for $3 \mathrm{~min}$; followed by five cycles of denaturation at $95^{\circ} \mathrm{C}$ for $30 \mathrm{sec}$, annealing at 57 to $53^{\circ} \mathrm{C}$ for $30 \mathrm{sec}$ (a temperature decrease of $1^{\circ} \mathrm{C}$ per cycle) and extension at $72^{\circ} \mathrm{C}$ for $30 \mathrm{sec}$; followed by 30 cycles of denaturation at $95^{\circ} \mathrm{C}$ for $30 \mathrm{sec}$, annealing at $53^{\circ} \mathrm{C}$ for $30 \mathrm{sec}$ and extension at $72^{\circ} \mathrm{C}$ for $30 \mathrm{sec}$; and a final extension at $72^{\circ} \mathrm{C}$ for $2 \mathrm{~min}$. The PCR products from the first round of amplification were used as the DNA template in the second round of amplification, which was performed using the same amplification conditions and reaction system as in the first round. The primers used for amplification were also used as the primers for sequencing. The information obtained from sequencing was assembled using the subprogram SeqMan of Lasergene software (Version 7.1.0; DNAstar, Inc.) followed by a comparison of the sequences using BLAST (https://blast.ncbi.nlm.nih.gov/Blast.cgi) (22).

Genotype and serotype analysis. MEGA v6.0 software (23) was used to compare and splice the $\mathrm{S}$ gene. The neighbor joining method was used for the homologous analysis of the sequences obtained from sequencing and the reference sequences of the genotypes downloaded from GenBank (24): A (GenBank accession nos, AF090842 and X02763), B (GenBank accession nos, AB033554, AF100309 and D00329), C (GenBank accession nos, AB014381, AY123041 and X04615), D (GenBank accession nos, M32138, X65259 and X85254), E (GenBank accession nos, AB032431 and X75657), F (GenBank accession nos, X69798, AB036910, AF223965), G (GenBank accession nos, AB064310, AF160501 and AF405706), and H (GenBank accession nos, AY090454, AY090457 and AY090460) (considered to be the same genotype when homology to the $\mathrm{S}$ gene was $\geq 96 \%$ ) (25). Serotypes were determined based on the expression of amino acids at specific sites in the sequence of the S gene according to the literature (26).

Grouping. According to the HBsAg levels measured and using $10 \mathrm{IU} / \mathrm{ml}$ as the cut-off value $(3,6,7)$, a total of 2,544 subjects were grouped into a low-level HBsAg group $(<10 \mathrm{IU} / \mathrm{ml})$ and a high-level HBsAg group ( $\geq 10 \mathrm{IU} / \mathrm{ml})(3,6,7)$. The high-level HBsAg group was further subdivided into three groups based on cut-off values, $100 \mathrm{IU} / \mathrm{ml}(19,20)$ and $200 \mathrm{IU} / \mathrm{ml}(16,20)$; the three groups included $\mathrm{a} \geq 10-100 \mathrm{IU} / \mathrm{ml}$ group, $\mathrm{a} \geq 100-200 \mathrm{IU} / \mathrm{ml}$ group and $\mathrm{a} \geq 200 \mathrm{IU} / \mathrm{ml}$ group.

PatientswithHBVinfectionwereclassifiedintosix serological pattern groups based on the presence of specific HBV serological markers (HBsAg, anti-HBs, $\mathrm{HBeAg}$, anti-HBe and anti-HBc). For convenience, HBV-M1, -M2, -M3, -M4, -M5 and -M6 were used to represent the $\mathrm{HBs} \mathrm{Ag} / \mathrm{HBeAg} / \mathrm{anti}-\mathrm{HBc}$-positive, HBsAg/anti-HBe/anti-HBc-positive, HBsAg/anti-HBc-positive, $\mathrm{HBsAg} / \mathrm{HBeAg} / \mathrm{anti}-\mathrm{HBe} / \mathrm{anti}-\mathrm{HBc}$-positive, HBsAg/anti-HBs/HBeAg/anti-HBc-positive, and HBsAg/anti$\mathrm{HBs} /$ anti-HBe/anti-HBc-positive serotype, respectively.

According to the laboratory test results for ALT and clinical diagnostic criteria (27-30), the patients with HBV infection were divided into asymptomatic carriers of $\mathrm{HBV}$ (ASC) and chronic HBV infection (CHB). ASCs is defined as HBsAg positivity for $>6$ months, low or undetectable serum HBV DNA levels and normal serum ALT levels $(<40 \mathrm{IU} / \mathrm{ml})$; CHBs is defined as HBsAg positivity for $>6$ months, abnormal or persistently elevated ALT (ALT $\geq 40 \mathrm{IU} / \mathrm{ml}$ ) and/or concomitant clinical manifestations of fatigue, nausea, abdominal distention, liver pain.

Using 10 years of age as the intergroup interval, the patients with $\mathrm{HBV}$ infection were divided into five age groups as follows: $<30, \geq 30-40, \geq 40-50, \geq 50-60$ and $\geq 60$ years of age.

Statistical analysis. The measurement data are expressed as the mean \pm standard deviation or median (quartiles), and the count data are expressed as $n(\%)$. The prevalence of positivity for HBsAg and HBV DNA, and the composition ratios of the different groups were compared using the Chi-squared test. The means of the different groups were compared based on 
Table I. Distribution of HBsAg-positive prevalence in all 45,256 individuals and in 2,544 HBsAg-positive subjects.

A, HBsAg-positive rate of all subjects

\begin{tabular}{|c|c|c|c|c|c|c|c|}
\hline \multirow[b]{2}{*}{ Group } & \multirow[b]{2}{*}{$\mathrm{n}$} & \multicolumn{5}{|c|}{ Group by HBsAg level (IU/ml) } & \multirow[b]{2}{*}{ P-value } \\
\hline & & $<10$ & $\geq 10-100$ & $\geq 100-200$ & $\geq 200$ & Total & \\
\hline \multicolumn{8}{|l|}{ Sex } \\
\hline Male & 28,959 & $260(0.90)$ & $208(0.72)$ & $197(0.68)$ & $998(3.45)$ & $1663(5.74)$ & $<0.05$ \\
\hline Female & 16,297 & $132(0.81)$ & $122(0.75)$ & $96(0.59)$ & $531(3.26)$ & $881(5.41)$ & $<0.05$ \\
\hline P-value & & $>0.05$ & $>0.05$ & $>0.05$ & $>0.05$ & $>0.05$ & \\
\hline \multicolumn{8}{|c|}{ Age (years) } \\
\hline$<30$ & 7,429 & $26(0.35)$ & $15(0.20)$ & $25(0.34)$ & $204(2.75)$ & $270(3.63)$ & $<0.05$ \\
\hline$\geq 30-40$ & 6,866 & $46(0.67)$ & $65(0.95)$ & $38(0.55)$ & $274(3.99)$ & $423(6.16)$ & $<0.05$ \\
\hline$\geq 40-50$ & 8,542 & $82(0.96)$ & $77(0.90)$ & $80(0.94)$ & $342(4.00)$ & $581(6.80)$ & $<0.05$ \\
\hline$\geq 50-60$ & 8,039 & $82(1.02)$ & $55(0.68)$ & $68(0.85)$ & $303(3.77)$ & $508(6.32)$ & $<0.05$ \\
\hline$\geq 60$ & 14,381 & $156(1.08)$ & $118(0.82)$ & $82(0.57)$ & $406(2.82)$ & $762(5.30)$ & $<0.05$ \\
\hline P-value & & $<0.05^{\mathrm{a}}$ & $<0.05$ & $<0.05$ & $<0.05$ & $<0.05$ & \\
\hline Total & 45,256 & $392(0.87)$ & $330(0.73)$ & $293(0.65)$ & $1,529(3.38)$ & $2,544(5.62)$ & $<0.05$ \\
\hline
\end{tabular}

B, HBV DNA-positive rate in HBsAg-positive subjects

Group by HBsAg level (IU/ml)

\begin{tabular}{|c|c|c|c|c|c|c|c|}
\hline \multirow[b]{2}{*}{ Group } & \multirow[b]{2}{*}{$\mathrm{n}$} & & \multirow[b]{2}{*}{ P-value } \\
\hline & & $<10$ & $\geq 10-100$ & $\geq 100-200$ & $\geq 200$ & Total & \\
\hline \multicolumn{8}{|l|}{ Sex } \\
\hline Male & 1,663 & $61(23.46)$ & $99(47.60)$ & 117 (59.39) & $978(98.00)$ & $1,255(75.47)$ & $<0.05$ \\
\hline Female & 881 & $36(27.27)$ & $55(45.08)$ & $63(65.63)$ & $508(95.67)$ & $662(75.14)$ & $<0.05$ \\
\hline P-value & & $>0.05$ & $>0.05$ & $>0.05$ & $>0.05$ & $>0.05$ & \\
\hline \multicolumn{8}{|c|}{ Age (years) } \\
\hline$<30$ & 270 & $6(23.08)$ & 7 (46.67) & $16(64.00)$ & $196(96.08)$ & $225(83.33)$ & $<0.05$ \\
\hline$\geq 30-40$ & 423 & $11(23.91)$ & $35(53.85)$ & $24(63.16)$ & $269(98.18)$ & $339(80.14)$ & $<0.05$ \\
\hline$\geq 40-50$ & 581 & $21(25.61)$ & $39(50.65)$ & $52(65.00)$ & $338(98.83)$ & $450(77.45)$ & $<0.05$ \\
\hline$\geq 50-60$ & 508 & $21(25.61)$ & $25(45.45)$ & $40(58.82)$ & $295(97.36)$ & $381(75.00)$ & $<0.05$ \\
\hline$\geq 60$ & 762 & $38(24.36)$ & $48(40.68)$ & $48(58.54)$ & 388 (95.57) & $522(68.50)$ & $<0.05$ \\
\hline P-value & & $>0.05$ & $>0.05$ & $>0.05$ & $>0.05$ & $<0.05^{b}$ & \\
\hline Total & 2,544 & 97 (24.74) & $154(46.67)$ & $180(61.43)$ & $1,486(97.19)$ & $1,917(75.35)$ & $<0.05$ \\
\hline
\end{tabular}

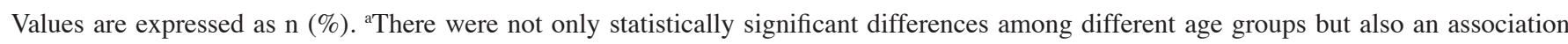
between HBsAg- and HBV DNA-positive prevalence and age according to logistic regression. ${ }^{\text {b }} \mathrm{HBV}$ DNA positivity was assessed using a routine method. According to the results obtained using the enrichment method, $12(12 / 26,46.15 \%), 21(21 / 46,45.65 \%), 38(38 / 82,46.34 \%)$, $37(37 / 82,45.12 \%)$ and $72(72 / 156,46.15 \%)$ of the subjects in the age groups of $<30, \geq 30-40, \geq 40-50, \geq 50-60$ and $\geq 60$ years, respectively, were positive for HBV DNA; there were no significant differences in HBV DNA-positive prevalence among the age groups. The difference appears to be associated with the proportion of HBV DNA positivity in the low-level HBsAg group and the $\geq 10-100 \mathrm{IU} / \mathrm{ml}$ group. HBV, hepatitis B virus; HBsAg, hepatitis B surface antigen.

the distribution types using the corresponding t-test or analysis of variance (ANOVA) for data with equal variances (assumed and not assumed), while the Student-Newman-Keuls (SNK)-q test was used to compare data among multiple groups, and the Mann-Whitney-U test and Kruskal-Wallis H-test were used for non-parametric data of two groups and multiple groups, respectively. Associations of HBV DNA, HBsAg and APRI with age, HBV markers and liver function indexes were analyzed using linear or logistic regression. A stepwise logistic regression model was used to test the association between outcome variables and associated factors whereby the variables with $\mathrm{P}<0.1$ on univariate analysis were subjected to multivariate logistic regression analysis. Plots were prepared using GraphPad Prism 6 for Windows (GraphPad Software, Inc.). Analysis of the data was performed using SPSS 12.01 for Windows. $\mathrm{P}<0.05$ was considered to indicate a statistically significant difference. 
Table II. Clinical laboratory parameters of 2,544 HBsAg-positive subjects with HBV infection.

\begin{tabular}{|c|c|c|c|c|}
\hline \multirow[b]{2}{*}{ Parameter } & \multicolumn{3}{|c|}{ Clinical type } & \multirow[b]{2}{*}{ P-value } \\
\hline & $\begin{array}{c}\text { ASC }(n=2,093) \\
\geq 10-100\end{array}$ & $\begin{array}{l}\text { CHB }(n=451) \\
\geq 200\end{array}$ & Total & \\
\hline \multicolumn{5}{|l|}{ Age (years) } \\
\hline Male & $45.02 \pm 12.34(n=1,539)$ & $43.18 \pm 12.31(n=124)$ & $44.87 \pm 12.36(n=1,663)$ & $<0.05$ \\
\hline Female & $46.85 \pm 13.14(n=827)$ & $42.05 \pm 9.84(\mathrm{n}=54)$ & $46.29 \pm 13.02(n=881)$ & $<0.05$ \\
\hline P-value & $>0.05$ & $>0.05$ & $>0.05$ & \\
\hline \multicolumn{5}{|l|}{ Liver function } \\
\hline ALB (mean $\pm \mathrm{SD}, 64 \sim 83 \mathrm{~g} / \mathrm{l})$ & $47.04 \pm 2.83$ & $43.28 \pm 1.80$ & $45.39 \pm 3.07$ & $<0.05$ \\
\hline ALT [median (Q1, Q3), <40 U/1] & $26(20,31)$ & $66(54,118)$ & $39(23,66)$ & $<0.05$ \\
\hline AST [median (Q1, Q3), <40 U/1] & $23(19,27)$ & $41(38,80)$ & $29(22,41)$ & $<0.05$ \\
\hline PLT $\left(\right.$ mean $\left.\pm \mathrm{SD}, 125 \sim 350 \times 10^{9} / 1\right)$ & $210.17 \pm 41.99$ & $187.59 \pm 28.45$ & $200.26 \pm 38.22$ & $<0.05$ \\
\hline TBil $($ Mean \pm SD, 3.42 20.52 $\mu \mathrm{mol} / \mathrm{l})$ & $16.66 \pm 6.60$ & $21.03 \pm 10.55$ & $18.58 \pm 8.80$ & $<0.05$ \\
\hline Fibrosis index APRI & $0.12(0.09,0.18)$ & $0.24(0.22,0.42)$ & $0.16(0.10,0.24)$ & $<0.05$ \\
\hline \multicolumn{5}{|l|}{ Virological result } \\
\hline HBsAg [median (Q1, Q3), <0.05 IU/ml] & $\begin{array}{c}631.12 \\
(52.40,3,376.50)\end{array}$ & $\begin{array}{c}3,957.50 \\
(1,288.95,1,5775.50)\end{array}$ & $\begin{array}{c}807.51 \\
(60.90,3,871.75)\end{array}$ & $<0.05$ \\
\hline Anti-HBs [median (Q1, Q3), <10 mIU/ml] & $0.22(0.00,0.95)$ & $0.11(0.00,0.63)$ & $0.21(0.00,0.93)$ & $<0.05$ \\
\hline HBeAg [median (Q1, Q3), <1.0 S/CO] & $0.39(0.34,0.48)$ & $0.49(0.38,371.90)$ & $0.39(0.34,0.59)$ & $<0.05$ \\
\hline Anti-HBe [median (Q1, Q3), >1.01 S/CO] & $0.01(0.01,0.79)$ & $0.18(0.01,35.20)$ & $0.01(0.01,1.08)$ & $<0.05$ \\
\hline Anti-HBc (mean $\pm \mathrm{SD},<1.0 \mathrm{~S} / \mathrm{CO})$ & $12.59 \pm 2.51$ & $11.87 \pm 2.35$ & $12.38 \pm 2.51$ & $>0.05$ \\
\hline $\mathrm{HBV}_{\mathrm{DNA}}^{\mathrm{a}}[$ median $(\mathrm{Q} 1, \mathrm{Q} 3), \log 10 \mathrm{IU} / \mathrm{ml}]$ & $2.88(0.00,4.04)$ & $6.99(3.82,7.97)$ & $3.03(0.00,4.57)$ & $<0.05$ \\
\hline
\end{tabular}

af the HBV DNA level was $<30 \mathrm{IU} / \mathrm{ml}$, the log value was considered to be $0 \mathrm{IU} / \mathrm{ml}$; if the HBV DNA level was $\geq 30 \mathrm{IU} / \mathrm{ml}$, the actual logarithm value was calculated. APRI, AST-to-platelet ratio; CHB, chronic HBV infection; ASC, asymptomatic HBV carriers; HBV, hepatitis B virus; $\mathrm{HBsAg}$, hepatitis B surface antigen; anti-HBs, antibody against HBsAg; HBeAg, hepatitis B e antigen; anti-HBe, antibody against $\mathrm{HBeAg}$; anti-HBc, antibody against hepatitis B core antigen; ALB, albumin; ALT, alanine aminotransferase; AST, aspartate aminotransferase; PLT, blood platelets; TBil, total bilirubin.

\section{Results}

HBsAg measurement and verification. To verify the accuracy of HBsAg determination, 100 of the 2,544 HBsAg-positive specimens were randomly selected and tested using a Maglumi 4000 analyzer and the supporting HBsAg kits; the results of this measurement were compared with the results obtained using the Architect i2000 analyzer and the matching HBsAg kits. The results indicated that the correlation between the two instruments was satisfactory [correlation coefficient $(\mathrm{r})=0.985 ; \mathrm{P}<0.05]$; furthermore, the r-value obtained for HBsAg $<10 \mathrm{IU} / \mathrm{ml}$ was 0.991 . To ensure the comparability of the results for HBsAg in the present study, the samples were grouped based on the quantitative results obtained using the Architect i2000 analyzer and the matching HBsAg kits.

HBsAg-positive prevalence in the cohort that underwent physical examination. Of the 45,256 subjects who underwent physical examination, 2,544 (5.62\%) were detected positive for HBsAg; of these 2,544 cases, 1,663 were male (1,663/28,959, $5.74 \%)$ and 881 were female $(881 / 16,297,5.41 \%)$. The number of cases with low-level HBsAg confirmed by the neutralization test was 392 , accounting for $0.87 \%$ of the 45,256 cases in the physical examination population $(392 / 45,256)$ and $15.41 \%$ of the 2,544 HBsAg-positive cases (392/2,544; Table I). There were no significant differences between the sexes in mean age or $\mathrm{HBsAg}$-positive prevalence $(\mathrm{P}>0.05)$, but differences were identified in the prevalence of $\mathrm{HBsAg}$ positivity among different HBsAg level groups and age groups $(\mathrm{P}<0.05$; Tables I and II). In addition, the HBsAg-positive prevalence exhibited a tendency to increase with age in the low-level HBsAg group according to linear regression $(\mathrm{P}<0.05$; Table I; Fig. 1A). Furthermore, an increase in the prevalence of HBsAg positivity in the distribution prior to 50 years of age and a decrease after 50 years of age was observed in the high-level HBsAg group (Fig. 1B). The lower prevalence of HBsAg positivity in patients aged $<30$ years in the high-level HBsAg group is likely to be linked to the implementation of an HBV vaccination program in China in 1992 (31). In addition, the lower prevalence of HBsAg in patients $>50$ years of age in the high-level HBsAg group may be associated with spontaneous HBsAg seroclearance; the levels of HBsAg and HBV DNA gradually decrease with age due to host-virus interactions (natural clearance phase) (32).

$H B V$ DNA-positive prevalence and clinical laboratory parameters in 2,544 cases of $\mathrm{HBV}$ infection. Of the 2,544 HBsAg-positive subjects, 2,093 were ASC and 451 had CHB. The male-to-female ratio was $\sim$ 1.9:1 (Table I). There were no 
Distribution of different levels HBsAg-positive prevalence in 45256 people with physical examination in age groups
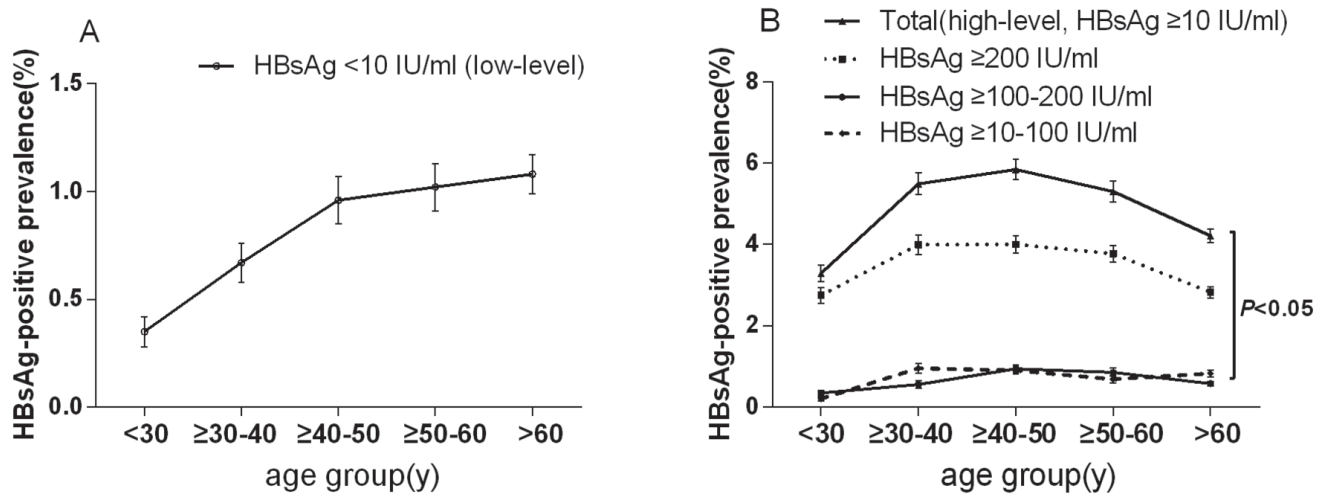

Distribution of HBV DNA-positive prevalence in $2544 \mathrm{HBsAg-positive} \mathrm{subjects} \mathrm{with} \mathrm{HBV} \mathrm{infections} \mathrm{in} \mathrm{age} \mathrm{groups}$
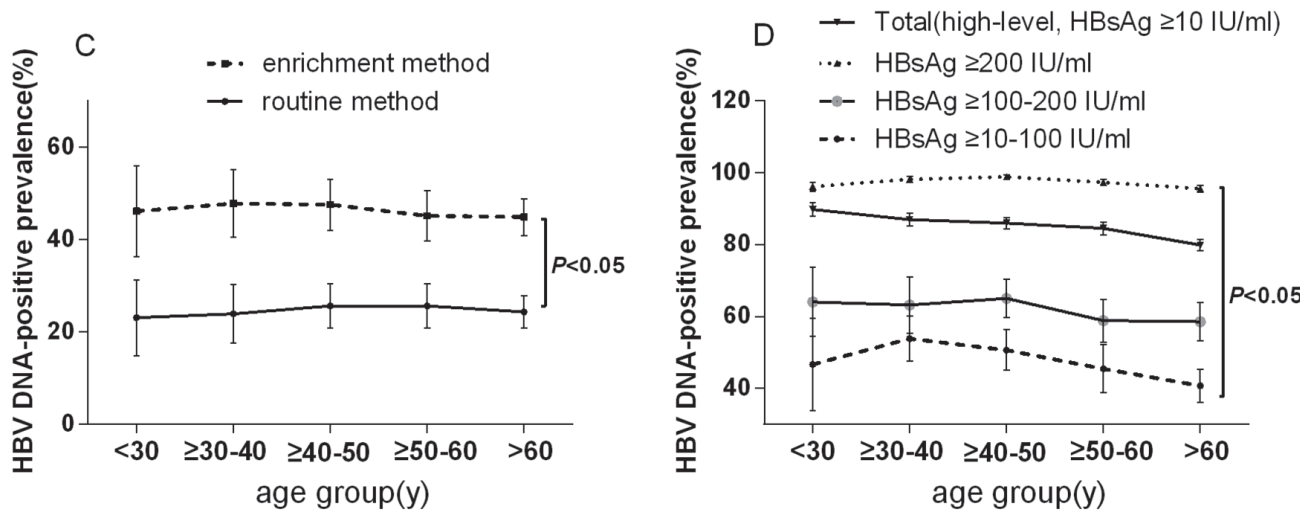

Figure 1. Distribution of the prevalence of different level HBsAg positivity and HBV DNA positivity in HBsAg-level groups according to age in a physical examination population. (A) Prevalence of HBsAg positivity in the low-level HBsAg group according to age in a physical examination population (B) Prevalence of different levels of HBsAg positivity in the high-level HBsAg groups ( $\geq 10-100, \geq 100-200$ or $\geq 200 \mathrm{IU} / \mathrm{ml}$ and total group) according to age in a physical examination population. $\mathrm{P}<0.05, \geq 10-100 \mathrm{IU} / \mathrm{ml}$ group vs. $\geq 100-200$ group, $\geq 10-100 \mathrm{IU} / \mathrm{ml}$ group vs. $\geq 200 \mathrm{IU} / \mathrm{ml}$ group and $\geq 10-100 \mathrm{IU} / \mathrm{ml}$ group vs. $\geq 200 \mathrm{IU} / \mathrm{ml}$ group. (C) Prevalence of HBV DNA positivity in the low-level HBsAg group according to age in a physical examination population. P $<0.05$, enrichment method group vs. routine method group. (D) Prevalence of HBV DNA positivity in the high-level HBsAg group $(\geq 10-100, \geq 100-200$ or $\geq 200 \mathrm{IU} / \mathrm{ml}$, and total group) according to age in a physical examination population. $\mathrm{P}<0.05, \geq 10-100 \mathrm{IU} / \mathrm{ml}$ group vs. $\geq 100-200$ group, $\geq 10-100 \mathrm{IU} / \mathrm{ml}$ group vs. $\geq 200 \mathrm{IU} / \mathrm{ml}$ group and $\geq 10-100 \mathrm{IU} / \mathrm{ml}$ group vs. $\geq 200 \mathrm{IU} / \mathrm{ml}$ group. HBV, hepatitis B virus; HBsAg, hepatitis B surface antigen; y, years.

significant differences in the HBV DNA-positive prevalence between the sexes or among age groups ( $\mathrm{P}>0.05$; Fig. $1 \mathrm{C}$ and $\mathrm{D})$. However, differences in the HBV DNA-positive prevalence were noted among the different HBsAg level groups $(\mathrm{P}<0.05$; Tables I and II), and the HBV DNA-positive prevalence in the low-level HBsAg group determined using the routine method was lower than the prevalence determined using the enrichment method $(\mathrm{P}<0.05$; Fig. $1 \mathrm{C})$. Except for anti-HBc, all of the clinical laboratory parameters of the 2,544 cases of HBV infection exhibited statistically significant differences between ASC and CHB ( $<<0.05$; Table II).

When the clinical laboratory parameters were analyzed with stratification by sex, statistically significant differences in the mean values of $\mathrm{HBeAg}$ (male, $122.90 \pm 349.76 \mathrm{~S} / \mathrm{CO}$; female, $125.62 \pm 383.38 \mathrm{~S} / \mathrm{CO}$ ), anti-HBc (male, $12.77 \pm 2.21$ $\mathrm{S} / \mathrm{CO}$; female, $12.19 \pm 2.94 \mathrm{~S} / \mathrm{CO}$ ) and mean $\log$ values of HBV DNA (male, $3.08 \pm 2.84 \mathrm{IU} / \mathrm{ml}$; female: $2.77 \pm 2.94 \mathrm{IU} / \mathrm{ml}$ ) between the two sexes became apparent $(\mathrm{P}<0.05)$. These differences may be linked to the presence of different HBV markers, serological patterns and clinical types in the two sexes and may therefore not be clinically meaningful (data not shown).
Distribution of serological patterns and clinical types among the 2,544 cases of HBV infection. The subjects were grouped based on an HBsAg threshold level of $10 \mathrm{IU} / \mathrm{ml}$. In the low-level HBsAg group, the major serological pattern was HBV-M2 (HBsAg/anti-HBe/anti-HBc-positive; 372/392, 94.90\%) and the major clinical type was ASC $(384 / 392,97.95 \%)$. In the high-level HBsAg group, the major serological patterns were HBV-M2 (HBsAg/anti-HBe/anti-HBc-positive; 1,627/2,152, 75.60\%) and HBV-M1 (HBsAg/HBeAg/anti-HBc-positive; $433 / 2,152,20.12 \%$ ), and the ratios of the clinical types ASC and CHB were $(1,709 / 2,152,79.41 \%)$ and $(443 / 2,152,20.59 \%)$ respectively (Table III). There were no significant differences in the major serological patterns and the major clinical types between the different HBsAg level groups $(<10, \geq 10-100$ and $\geq 100-200 \mathrm{IU} / \mathrm{ml} ; \mathrm{P}>0.05$; Fig. $2 \mathrm{~A}$ vs. $2 \mathrm{~B}$ vs. $2 \mathrm{C}$ ), whereas there were significant differences in the major serological patterns and major clinical types between the three groups $(<10$, $\geq 10-100$ and $\geq 100-200 \mathrm{IU} / \mathrm{ml}$ ) and $\mathrm{HBsAg} \geq 100-200 \mathrm{IU} / \mathrm{ml}$ group ( $\mathrm{P}<0.05$, Fig. 2A-C vs. 2D).

As presented in Table III, the mean age of the patients with the major serological patterns and the major clinical types in the low-level HBsAg group, as well as the mean age of the 
Table III. Distribution of serological patterns and clinical types in 2,544 subjects with chronic HBV infection in two groups.

A, Low-level HBsAg group $(\mathrm{n}=392)$

\begin{tabular}{|c|c|c|c|c|c|c|c|}
\hline \multirow[b]{2}{*}{ Classification } & \multirow[b]{2}{*}{ Age (years) } & \multicolumn{3}{|c|}{ HBsAg-positive (n) } & \multicolumn{3}{|c|}{ HBV DNA-positive (n) } \\
\hline & & Male $(\%)$ & Female $(\%)$ & Total & Male & Female & Total \\
\hline \multicolumn{8}{|l|}{ Serological pattern (n, \%) } \\
\hline HBV-M1 $(3,0.77)$ & $56.00 \pm 15.72^{\mathrm{a}}$ & $3(0.77)$ & $0(0)$ & $3^{\mathrm{d}}$ & $3(3)$ & $0(0)$ & $3(3)$ \\
\hline HBV-M2 $(372,94.90)$ & $55.37 \pm 16.23^{\mathrm{a}}$ & $244(62.24)$ & $128(32.65)$ & $372^{\mathrm{d}}$ & $52(117)$ & $38(51)$ & $90(168)^{\mathrm{e}}$ \\
\hline HBV-M3 $(10,2.55)$ & $58.48 \pm 9.78$ & $7(1.79)$ & $3(0.77)$ & 10 & $3(4)$ & $0(1)$ & $3(5)$ \\
\hline HBV-M4 $(3,0.77)$ & $55.11 \pm 13.25$ & $2(0.51)$ & $1(0.26)$ & 3 & $0(1)$ & $0(1)$ & $0(2)$ \\
\hline HBV-M5 $(2,0.51)$ & $49.00 \pm 12.73$ & $2(0.51)$ & $0(0)$ & 2 & $1(1)$ & $0(0)$ & $1(1)$ \\
\hline HBV-M6 $(2,0.51)$ & $50.50 \pm 3.54$ & $2(0.51)$ & $0(0)$ & 2 & $0(1)$ & $0(0)$ & $0(1)$ \\
\hline \multicolumn{8}{|l|}{ Clinical type (n, \%) } \\
\hline ASC $(384,97.95)$ & $54.99 \pm 16.43^{\mathrm{a}}$ & $253(64.54)$ & $131(33.42)$ & $384^{\mathrm{d}}$ & $55(122)$ & $38(52)$ & $93(174)^{\mathrm{e}}$ \\
\hline $\mathrm{CHB}(8,2.05)$ & $51.36 \pm 22.95$ & $7(1.79)$ & $1(0.26)$ & $8^{\mathrm{e}}$ & $4(5)$ & $0(1)$ & $4(6)$ \\
\hline Total & $54.98 \pm 16.28^{\mathrm{a}}$ & $260(66.33)^{b}$ & $132(33.67)^{b}$ & $392^{\mathrm{e}}$ & $59(127)$ & $39(53)$ & $97(180)^{\mathrm{e}}$ \\
\hline
\end{tabular}

B, High-level HBsAg group ( $\mathrm{n}=2,152)$

\begin{tabular}{|c|c|c|c|c|c|c|c|}
\hline \multirow[b]{2}{*}{ Classification } & \multirow[b]{2}{*}{ Age (years) } & \multicolumn{3}{|c|}{ HBsAg-positive (n) } & \multicolumn{3}{|c|}{ HBV DNA-positive (n) } \\
\hline & & Male (\%) & Female $(\%)$ & Total & Male & Female & Total \\
\hline \multicolumn{8}{|l|}{ Serological pattern $(\mathrm{n}, \%)$} \\
\hline HBV-M1 $(433,20.12)$ & $39.13 \pm 9.87$ & $297(13.80)$ & $136(6.32)$ & 433 & 297 & 136 & 433 \\
\hline HBV-M2 $(1,627,75.60)$ & $45.02 \pm 10.84^{\mathrm{b}}$ & $1,048(48.70)$ & $579(26.91)$ & 1,627 & 873 & 456 & 1,329 \\
\hline HBV-M3 $(78,3.62)$ & $45.29 \pm 10.75^{\mathrm{b}}$ & $47(2.18)$ & $31(1.44)$ & 78 & 29 & 21 & 50 \\
\hline HBV-M4 $(6,0.28)$ & $42.54 \pm 15.16$ & $5(0.23)$ & $1(0.05)$ & 6 & 3 & 1 & 4 \\
\hline HBV-M5 $(4,0.19)$ & $43.78 \pm 14.51$ & $3(0.14)$ & $1(0.05)$ & 4 & 2 & 0 & 2 \\
\hline HBV-M6 (4, 0.19) & $44.11 \pm 15.34$ & $3(0.14)$ & $1(0.05)$ & 4 & 2 & 0 & 2 \\
\hline \multicolumn{8}{|l|}{ Clinical type (n, \%) } \\
\hline $\operatorname{ASC}(1,709,79.41)$ & $43.97 \pm 10.85^{\mathrm{b}}$ & $1,098(51.02)$ & $611(28.39)$ & 1,709 & 904 & 4,774 & 1,381 \\
\hline CHB $(443,20.59)$ & $41.79 \pm 11.54^{\mathrm{c}}$ & 305 (14.17) & $138(6.41)$ & 443 & 302 & 137 & 439 \\
\hline Total & $43.63 \pm 10.97$ & $1,403(65.20)$ & $749(34.80)$ & 2,15 & 1,206 & 614 & 1,820 \\
\hline \multicolumn{8}{|c|}{ 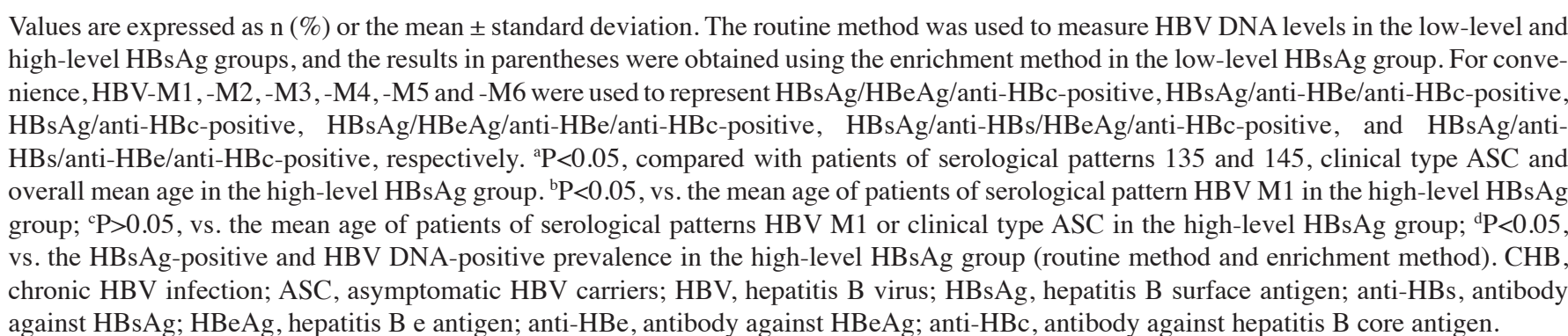 } \\
\hline
\end{tabular}

entire low-level HBsAg group, were higher than the mean age of the patients in the high-level HBsAg group $(\mathrm{P}<0.05)$. In addition, in the high-level HBsAg group, the mean age of the patients with the serological pattern HBV-M1 was lower than that of the patients with the HBV-M2 and HBV-M3 patterns and the clinical subtype ASC $(\mathrm{P}<0.05)$. The positive prevalence of HBsAg and HBV DNA (determined by the routine method and the enrichment method) was lower, and the proportions of HBV-M2 and ASC were higher in the low-level HBsAg group than in the high-level HBsAg group $(\mathrm{P}<0.05)$. However, no significant differences were determined in the gender distribution of the HBsAg-positive and HBV DNA-positive patients with the routine method or the enrichment method among the major serological patterns and clinical types in the high- and low-level HBsAg groups (P>0.05; Table III). 
A Low-level HBsAg group (<10IU/ml)

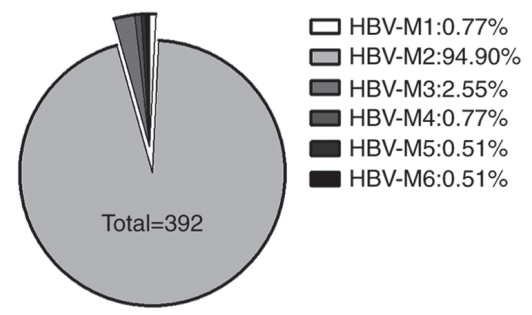

C High-level HBsAg group ( $\geq 100-200 \mathrm{IU} / \mathrm{ml})$

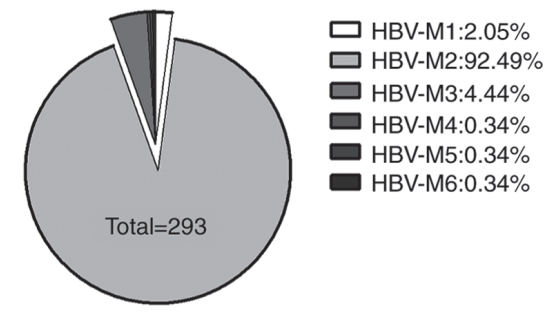

E Low-level HBsAg group (<10IU/ml)

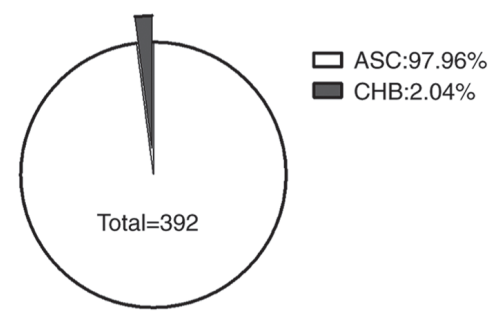

G High-level HBsAg group ( $\geq 100-200 \mathrm{IU} / \mathrm{ml})$

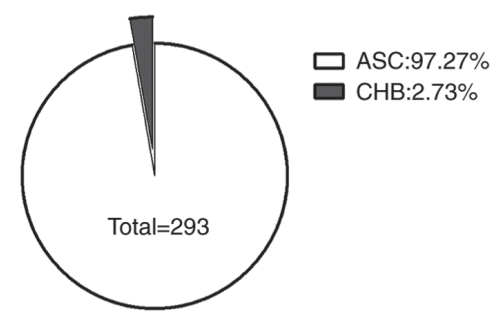

B High-level HBsAg group $(\geq 10-100 \mathrm{IU} / \mathrm{ml})$

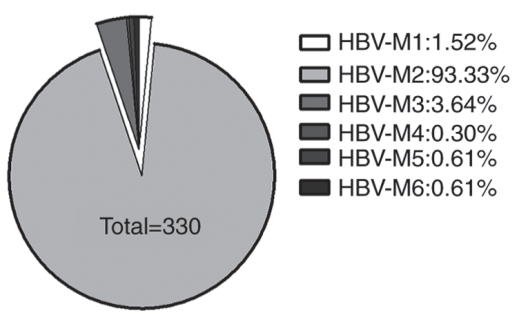

D High-level HBsAg group ( $\geq 200 \mathrm{IU} / \mathrm{ml})$

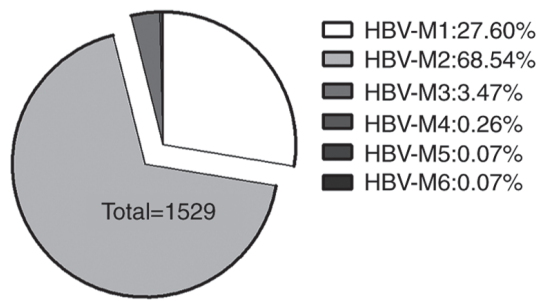

F High-level HBsAg group ( $\geq 10-100 \mathrm{IU} / \mathrm{ml})$

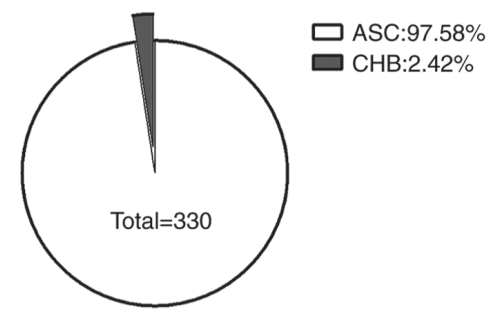

H High-level HBsAg group ( $\geq 200 \mathrm{IU} / \mathrm{ml})$

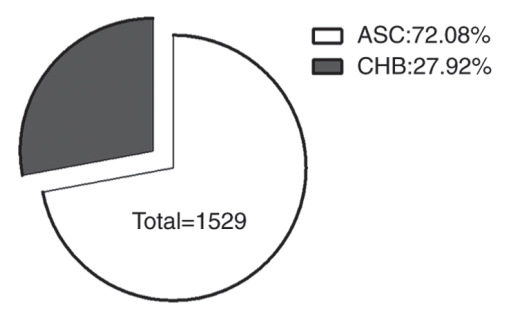

Figure 2. Proportions of patients with specific HBV serological patterns and clinical types in the HBsAg level groups. (A) Distribution of different serological patterns of HBV in low-level HBsAg group ( $<10 \mathrm{IU} / \mathrm{ml}$ ). (B) Distribution of different serological patterns of HBV in high-level HBsAg group ( $\geq 10-100 \mathrm{IU} / \mathrm{ml}$ ). (C) Distribution of different serological patterns of HBV in high-level HBsAg group ( $\geq 100-200 \mathrm{IU} / \mathrm{ml})$. (D) Distribution of different serological patterns of HBV in high-level HBsAg group ( $\geq 200 \mathrm{IU} / \mathrm{ml}$ ). (E) Distribution of different clinical types of HBV in low-level HBsAg group ( $<10 \mathrm{IU} / \mathrm{ml})$. (F) Distribution of different clinical types of HBV in high-level HBsAg group ( $\geq 10-100 \mathrm{IU} / \mathrm{ml})$. (G) Distribution of different clinical types of $\mathrm{HBV}$ in high-level HBsAg group $(\geq 100-200 \mathrm{IU} / \mathrm{ml})$. (H) Distribution of different clinical types of HBV in high-level HBsAg group $(\geq 200 \mathrm{IU} / \mathrm{ml})$. There were no significant differences in the major serological patterns and the major clinical types between the different HBsAg level groups $(<10, \geq 10-100$ and $\geq 100-200 \mathrm{IU} / \mathrm{ml}$; P $>0.05$; Fig. 2A vs. $2 \mathrm{~B}$ vs. $2 \mathrm{C}$ ), but there were significant differences in the major serological patterns and the major clinical types between the three groups $(<10, \geq 10-100$ and $\geq 100-200 \mathrm{IU} / \mathrm{ml}$ ) and HBsAg $\geq 100-200 \mathrm{IU} / \mathrm{ml}$ group. P $<0.05$, Fig. 2A, B, C vs. 2D. For convenience, HBV-M1, -M2, -M3, -M4, -M5 and -M6 were used to represent HBsAg/HBeAg/anti-HBc-positive, HBsAg/anti-HBe/anti-HBc-positive, HBsAg/anti-HBc-positive, HBsAg/HBeAg/anti-HBe/anti-HBc-positive, HBsAg/anti-HBs/HBeAg/anti-HBc-positive and HBsAg/anti-HBs/anti-HBe/anti-HBc-positive, respectively. HBV, hepatitis B virus; HBsAg, hepatitis B surface antigen; anti-HBs, antibody against $\mathrm{HBsAg}$; HBeAg, hepatitis B e antigen; anti-HBe, antibody against $\mathrm{HBeAg}$; anti-HBc, antibody against hepatitis B core antigen; ASC, asymptomatic HBV carriers; $\mathrm{CHB}$, chronic $\mathrm{HBV}$ infection.

Comparison and association analysis of HBV DNA with $H B V$ markers of the major serological patterns and clinical types. After grouping the subjects based on their HBsAg levels $(<10, \geq 10-100, \geq 100-200$ and $\geq 200 \mathrm{IU} / \mathrm{ml})$, ANOVA or non-parametric tests were used to analyze the differences in major serological patterns and clinical types in the different HBsAg level groups. The mean values of log HBV DNA, $\mathrm{HBsAg}, \mathrm{HBeAg}$ and anti-HBc of ASC patients and patients with the serological pattern HBV-M2 in the low-level HBsAg group were lower than those in the high-level HBsAg group $(\mathrm{P}<0.05$; Table IV), whereas the mean levels of anti-HBs and anti-HBe in the low-level HBsAg group were higher than those in the high-level HBsAg group $(\mathrm{P}<0.05$; Table IV). In the high-level HBsAg group, there were significant differences in the mean values of HBV markers and age for patients with the serological pattern HBV-M1 among serological patterns and between clinical types $(\mathrm{P}<0.05$; Table IV). 


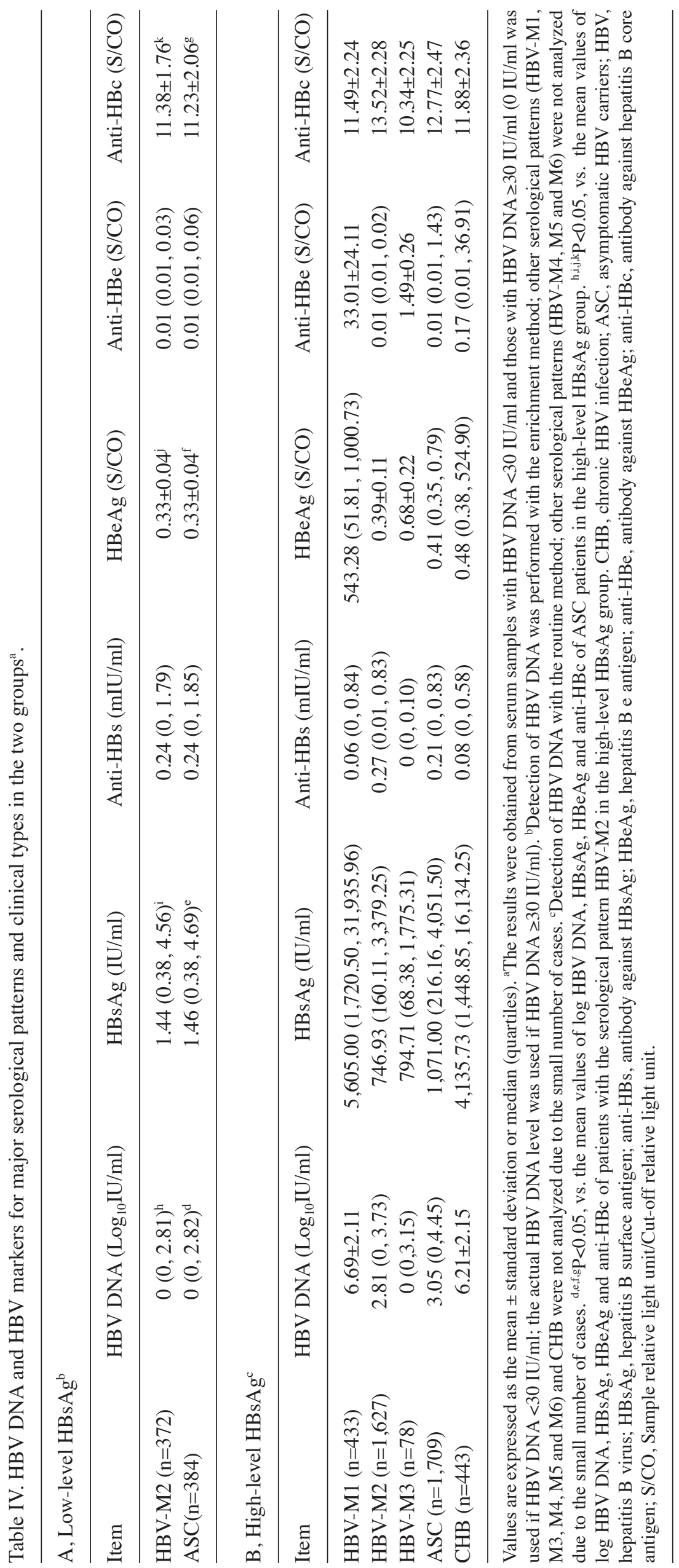


Table V. Analysis of the association of HBV DNA with age and HBV markers of the serological pattern HBV-M2 ${ }^{\mathrm{a}, \mathrm{b}}$.

\begin{tabular}{|c|c|c|c|c|}
\hline Group/category/associated variables & $\mathrm{B}$ & Wald $\chi^{2}$ & P-value & OR $(95 \% \mathrm{CI})$ \\
\hline \multicolumn{5}{|l|}{ Low-level HBsAg } \\
\hline \multicolumn{5}{|l|}{ HBV-M2 (HBsA g<10 IU/ml) } \\
\hline HBsAg & 0.26 & 17.07 & $<0.05$ & $1.30(1.15-1.47)$ \\
\hline \multicolumn{5}{|l|}{ High-level HBsAg } \\
\hline \multicolumn{5}{|l|}{ HBV-M2 (HBsAg $\geq 10-100$ IU/ml) } \\
\hline Anti-HBc & 0.49 & 12.18 & $<0.05$ & $1.62(1.24-2.13)$ \\
\hline \multicolumn{5}{|l|}{ HBV-M2 (HBsAg $\geq 100-200 \mathrm{IU} / \mathrm{ml})$} \\
\hline Anti-HBc & 0.12 & 11.28 & $<0.05$ & $1.16(1.05-1.28)$ \\
\hline \multicolumn{5}{|l|}{ HBV-M2 (HBsAg $\geq 200$ IU/ml) } \\
\hline Anti-HBe & 1.51 & 6.99 & $<0.05$ & $4.52(1.48-13.83)$ \\
\hline Anti-HBc & 0.18 & 15.25 & $<0.05$ & $1.20(1.11-1.30)$ \\
\hline \multicolumn{5}{|l|}{ HBV-M2 (HBsAg $\geq 10-100$ IU/ml) } \\
\hline Anti-HBs & 0.14 & 5.23 & $<0.05$ & $1.15(1.02-1.30)$ \\
\hline Anti-HBe & 0.98 & 4.14 & $<0.05$ & $2.67(1.04-6.88)$ \\
\hline Anti-HBc & 0.21 & 29.17 & $<0.05$ & $1.23(1.14-1.33)$ \\
\hline \multicolumn{5}{|l|}{ HBV-M1 (HBsAg $\geq 10-100 \mathrm{IU} / \mathrm{ml})^{\mathrm{c}}$} \\
\hline Anti-HBs & 0.13 & 2.43 & $<0.05$ & $0.13(0.03-0.24)$ \\
\hline Anti-HBe & 0.04 & 4.72 & $<0.05$ & $0.04(0.02-0.05)$ \\
\hline \multicolumn{5}{|l|}{ HBV-M3 (HBsAg $\geq 10-100 \mathrm{IU} / \mathrm{ml})^{\mathrm{d}}$} \\
\hline Anti-HBs & 1.19 & 2.51 & $<0.05$ & $1.18(0.23-2.15)$ \\
\hline
\end{tabular}

${ }^{a}$ Determination of HBV DNA by the enrichment method. ${ }^{b}$ The association of clinical types was not analyzed due to the presence of mixed serological patterns. ${ }^{\circ}$ The data were analyzed by linear regression, as the majority of HBV DNA-positive cases exhibited the serological pattern HBV-M1. ${ }^{\mathrm{d}}$ The data were not grouped due to the small number of cases with the serological pattern HBV-M3. For convenience, HBV-M1, M2 and $\mathrm{M} 3$ were used to represent $\mathrm{HBsAg} / \mathrm{HBeAg} / \mathrm{anti}-\mathrm{HBc}$-positive, $\mathrm{HBs} \mathrm{Ag} /$ anti-HBe/anti-HBc-positive and $\mathrm{HBs} \mathrm{Ag} /$ anti-HBc-positive, respectively. OR, odds ratio; HBV, hepatitis B virus; HBsAg, hepatitis B surface antigen; anti-HBs, antibody against HBsAg; HBeAg, hepatitis B e antigen; anti-HBe, antibody against $\mathrm{HBeAg}$; anti-HBc, antibody against hepatitis B core antigen.

The association of HBV DNA positivity with the HBV markers for patients with the serological pattern HBV-M1, M2 and M3 were analyzed using logistic regression in the high-level and low-level HBsAg groups (Table V). The HBV DNA-positive prevalence was associated with HBsAg of serological HBV-M2 only in the low-level HBsAg group (OR: 1.30 ; 95\% CI: 1.15-1.47; $\mathrm{P}<0.05$ ) and was associated with anti-HBs, anti-HBe and/or anti-HBc of the HBV-M2, HBV-M1 and HBV-M3 serological patterns in the high level HBsAg group $(\mathrm{P}<0.05)$. The HBV DNA-positive prevalence was not associated with age or HBeAg in either the low- or the high-level HBsAg group ( $\mathrm{P}>0.05$; data not shown).

Comparison and association analysis of APRI with HBsAg, $H B V$ DNA and liver function. The 1,980 cases of ASC in the high-level HBsAg group were divided into three subgroups based on their HBsAg levels ( $\geq 10-100, \geq 100-200$ and $\geq 200 \mathrm{IU} / \mathrm{ml}$ ). With the exception of HBV DNA and age in subjects with ASC, there were no statistically significant differences in APRI, ALT, AST, PLT, TBil or ALB among the HBsAg level groups $(<10, \geq 10-100, \geq 100-200$ and $\geq 200 \mathrm{IU} / \mathrm{ml})$ according the SNK-q test $(\mathrm{P}>0.05)$ or the Kruskal-Wallis H-test $(\mathrm{P}>0.05$; Table VI).
Results of serotype and genotype tests in the low-level and high-level HBsAg groups. The $\mathrm{S}$ gene sequencing success rate in the low-level HBsAg group $(78.35 \%, 76 / 97)$ was lower than that in the high-level HBsAg group (94.0\%, 94/100; $\mathrm{P}<0.05)$. The major serotype of the low-level HBsAg group was adw $(85.53 \%, 65 / 76)$ and the major genotype was B $(89.47 \%$, 68/76). There were statistically significant differences between the low-level and high-level HBsAg groups in the distribution of serotypes and genotypes $(\mathrm{P}<0.05$; Table VII).

\section{Discussion}

China is among the countries with the highest prevalence of HBV infection. HBV infection in China is mainly caused by perinatal or early childhood transmission (33). Since the launching of a nationwide HBV vaccination program for neonates by the National Health and Family Planning Commission of the P.R. China in 1992, significant progress has been made in the control of the HBV epidemic. The prevalence of HBsAg was reduced to $2.1 \%$ among all children (born during the period of 1992-2001) and to $1.0 \%$ among children born after 1999. Universal HBV vaccination of infants has led to a marked decrease in HBV epidemiology, with the 
prevalence of HBsAg positivity declining from $9.75 \%$ in 1992 to $7.18 \%$ in $2006(31,34)$. The results of the present study indicated that the prevalence of HBsAg positivity in adults was $5.62 \%$; this lower rate may be mainly due to the popularization of HBV vaccination (31), the widespread use of clinical anti-viral drugs (35) and the application of sensitive diagnostic reagents (3,36-38). It was revealed that patients with HBV infection and low HBsAg levels accounted for $15.41 \%(392 / 2,544)$ of the total HBsAg-positive population (2,544 patients) and that the HBsAg-positive prevalence demonstrated a tendency to increase with age based on logistic regression analysis (OR: 1.232; 95\% CI: 1.15-1.33; $\mathrm{P}<0.05$ ) and linear-by-linear association $(\mathrm{P}<0.05)$. The male-to-female ratio was $\sim 1.9: 1$ for low-level HBsAg patients; this was similar to the ratio in the high-level HBsAg group, but the average age of the low-level HBsAg group $(54.98 \pm 16.28$ years) was higher than that of the high-level HBsAg group ( $43.63 \pm 10.97$ years). In the low-level HBsAg group, the major serological pattern and clinical type were HBV-M1 (94.90\%) and ASC (97.95\%), respectively. HBV DNA had a low-level of replication and the positive prevalence of HBV DNA detection by the routine method and the enrichment method was $27.74 \%$ (97/392) and $45.92 \%$ (180/392), respectively. There were no significant differences among the age groups in the different HBsAg level groups $(\mathrm{P}>0.05)$. The HBV DNA-positive prevalence was associated with HBsAg of the serological pattern HBV-M2 only in the low-level HBsAg group (OR: 1.30; 95\% CI: 1.15-1.47; P<0.05). The hepatic fibrosis index APRI was not associated with age, HBsAg, HBV DNA or liver function index in ASC patients in the low-level HBsAg group $(\mathrm{P}>0.05)$. Serotype adw $(85.53 \%)$ and genotype B (89.47\%) were prevalent in the low-level HBsAg group.

In the present study, $\mathrm{HBsAg}<10 \mathrm{IU} / \mathrm{ml}$ was selected as the cut-off value for defining a low-level HBsAg population. The major reason for this is as follows: Since the late 1990s, our group has been continuously engaged in the study of HBV-infected populations with low-level HBsAg. At that time, the standard HBsAg serum concentrations of $2 \mathrm{ng} / \mathrm{ml}$ (critical level), $5 \mathrm{ng} / \mathrm{ml}$ (low-level) and $400 \mathrm{ng} / \mathrm{ml}$ (high-level) were provided by the Center of Clinical Laboratory, Ministry of Public Health, China (standard substance no. 9807). In 2002 , our group performed a study on the distribution of HBV infection with low-level HBsAg $(<5 \mathrm{ng} / \mathrm{ml})$ in a Chinese population (3). Based on the results, the HBsAg standard serum level of $5 \mathrm{ng} / \mathrm{ml}$ was adopted as a basis for defining a population with low-level HBsAg. In fact, the low-level HBsAg standard serum concentration of $5 \mathrm{ng} / \mathrm{ml}$ is equivalent to 0.80 Abs (ELISA), 72S/N (Microparticle Enzyme Immunoassay, MEIA) and $10 \mathrm{IU} / \mathrm{ml}$ (CMIA) (3,6,7,33). To ensure the comparability of the study results, an $\mathrm{HBsAg}$ level of $10 \mathrm{IU} / \mathrm{ml}$ was always used as the low-level threshold for grouping.

It is known that the fibrosis status of HBsAg carriers affects their clinical outcome. HBV infection may cause liver fibrosis, leading to cirrhosis and hepatocellular carcinoma. In the present study, the fibrosis status of ASCs with low-level HBsAg was assessed by determining the APRI. The results indicated that the APRI was not associated with age, $\mathrm{HBsAg}$ level, $\log$ HBV DNA or liver function index in ASCs with low-level HBsAg $(\mathrm{P}>0.05)$, but that it was associated with age (B: 0.09; 95\% CI: 0.05-0.14, $\mathrm{P}<0.05$ ) in ASCs with high-level HBsAg. APRI was associated with log HBsAg (B: -0.59; 
Table VII. Serotypes and genotypes (determined by sequencing) in the low-level and high-level HBsAg groups.

\begin{tabular}{lccccccr}
\hline & & \multicolumn{3}{c}{ Serotype (\%) } & & \multicolumn{2}{c}{ Genotype (\%) } \\
Group & Sequencing success $(\%)$ & adr & adw & ayw & & B & C \\
\hline Low-level HBsAg $(\mathrm{n}=97)$ & $76(78.35)$ & $8(10.53)$ & $65(85.53)$ & $3(3.95)$ & & $68(89.47)$ & $8(10.53)$ \\
High-level HBsAg $(\mathrm{n}=100)$ & $94(94.00)$ & $37(39.36)$ & $55(58.51)$ & $2(2.13)$ & & $52(55.32)$ & $42(44.68)$ \\
$\chi^{2}$ & 10.20 & 18.02 & & & & 23.61 & \\
P-value & $<0.05$ & $<0.05$ & & & & $<0.05$ \\
\hline
\end{tabular}

HBsAg, hepatitis B surface antigen.

95\% CI: $-0.89-0.33, \mathrm{P}<0.05)$, age (B: 0.05; 95\% CI: 0.03-0.09, $\mathrm{P}<0.05)$ and ALB (B: $-0.11 ; 95 \% \mathrm{CI}:-0.19-0.07, \mathrm{P}<0.05)$ in $\mathrm{CHB}$ patients with high-level HBsAg. It is indicated that the level of HBsAg in CHB patients gradually decreases with the aggravation of liver inflammation and fibrosis, as also reported by Zhong et al (39). In ASCs with low-level HBsAg, spontaneous clearance of HBsAg is common (16), whereas spontaneous clearance of HBsAg in ASCs with high-level $\mathrm{HBsAg}$ was between $\mathrm{CHB}$ patients with high-level $\mathrm{HBsAg}$ and ASC with low-level HBsAg. Such cases may develop into ASCs with spontaneous clearance of HBsAg or they may develop into cases of CHB (40).

A previous study by our group reported that low $\mathrm{HBsAg}$ levels were not associated with low HBV DNA replication (6); however, this may be due the fact that the Abbott AXSYM immunoassay analyzer used at that time had a low accuracy to quantify HBsAg (qualitative kit with an HBsAg units of $\mathrm{S} / \mathrm{N})$, and PCR primarily had a low sensitivity for the quantification of low-level HBV DNA $(<1,000$ copies/ml) (41). With enhanced capabilities for the detection of HBV markers and HBV DNA, low HBsAg $(<0.05 \mathrm{IU} / \mathrm{ml}$ ) and HBV DNA (nucleic acids extracted using immunomagnetic beads, $<30 \mathrm{IU} / \mathrm{ml})$, low-level analytes may be accurately quantified $(42,43)$. In the present study, a routine method and an enrichment method were used to perform HBV DNA extraction and measurement in the low-level HBsAg group, yielding positive percentages of $24.74 \%$ (97/392) and 45.92\% (180/392), respectively. These prevalences are higher than those reported in the literature for the routine method $(10.3 \%)$ and the enrichment method (34.6\%) (44). Therefore, the present re-assessment of the low-level HBsAg population contributes relevant clinical, epidemiological and molecular biological information.

The low-level HBsAg population may be classified as a single serological pattern (HBsAg/anti-HBe/anti-HBc-positive) or as ASCs according to the clinical classification used. These patients are in an inactive state according to their HBV infection history $(26,27)$. The present results indicated that in the low-level HBsAg group, the major serological pattern was HBV-M2 (HBsAg/anti-HBe/anti-HBc-positive) (94.90\%) and the major clinical type was ASC (97.95\%), while in the high-level HBsAg group, the major serological pattern and the major clinical type were still HBV-M2 (75.60\%) and ASC (79.41\%). A previous study reported significant positive correlations between the HBsAg and HBeAg levels, and between the HBsAg and HBV DNA levels. This may be the major reason for the prevalence of HBV-M2 and ASC in the low-level HBsAg group (45). In the present study, a detailed analysis of multiple aspects of the clinical characteristics of the low-level HBsAg population was performed (HBsAg level, serological pattern, clinical type, sex and age grouping). Further characteristics of this population regarding the serological pattern, genotype and nucleic acid sequences will be presented in a subsequent study.

The occurrence of low-level HBsAg may be the result of the natural clearance of chronic infection in certain populations $(38,39)$. However, preliminary analyses in previous studies by our group provided other possible explanations $(6,7)$. The presence of low-level HBsAg populations in which an overwhelming majority of infected persons are in the inactive state or asymptomatic cannot be entirely attributed to mutations in the $\mathrm{S}$ gene. The function of the entire HBV genome may affect HBsAg expression, resulting in a low total HBsAg concentration, or alternatively, the individual's immune system may not be able to completely remove HBsAg and its immune complex after HBV infection; thus, HBsAg may be maintained at a low-level over a long period of time. This phenomenon would be expected to induce a certain degree of immune tolerance. Therefore, systematic research on low-level HBsAg populations has important clinical and epidemiological significance for the improvement of HBV serological marker detection, clarification of the mechanism of the production of low-level HBsAg, examination of the ability to overcome immune tolerance and eliminate $\mathrm{HBV}$ infection, and prevention of $\mathrm{HBV}$ transmission.

\section{Acknowledgements}

Not applicable.

\section{Funding}

The present study was supported by the Medical Science Foundation of Nanjing Military Command (grant no. 12 MA117) and the Natural Science Foundation of Zhejiang Province (grant no. Y15H200001).

\section{Availability of data and materials}

The datasets used and/or analyzed during the present study are available from the corresponding author on reasonable request. 


\section{Authors' contributions}

JC participated in the project design and research, performed the statistical analysis, and was responsible for drafting and revision of the manuscript. XXJ participated in the project design and coordination, assisted in writing the manuscript and helped with the statistical analysis. DWC was responsible for sample collection. YZD performed the virological analysis and helped with the drafting of the manuscript. XJX performed the molecular genetic analysis and sample collection. HJZ, CGS and FHC performed the virological analysis and sample collection and participated in performing the statistical analysis. All authors read and approved the final manuscript.

\section{Ethics approval and consent to participate}

Prior to enrolment, all patients provided their written informed consent to participate in the study. The study was approved by the medical ethics committee of the hospital (the 117th Hospital of the PLA; protocol no. PLA-117-20160518).

\section{Patient consent for publication}

Not applicable.

\section{Competing interests}

The authors declare that they have no competing interests.

\section{References}

1. Couroucée AM, Drouet J, LeMarrec N, Drouet A and Soulier JP Blood donors positive for HBsAg and negative for anti-HBc antibody. Vox Sang 49: 26-33, 1985.

2. Raafat A, Yates P, Sellers F, Munro H and Dow B: Benefit of dynamic over static incubation in the detection of a low-leve HBsAg (chronic carrier) bone donor. Vox Sang 74: 56-58, 1998.

3. Chen Y and Wu W: Determination of low level HBsAg in serum by microparticle enzyme immunoassay. Hepatobiliary Pancreat Dis Int 1: 262-264, 2002.

4. Satoh K, Iwata-Takakura A, Yoshikawa A, Gotanda Y, Tanaka T, Yamaguchi T and Mizoguchi H: A new method of concentrating hepatitis B virus (HBV) DNA and HBV surface antigen: An application of the method to the detection of occult HBV infection. Vox Sang 95: 174-180, 2008.

5. Fei CR, Ye AQ and Zhang J: Evaluation of different methods in determination of low level HBsAg. Zhejiang Da Xue Xue Bao Yi Xue Ban 40: 436-439, 2011 (In Chinese).

6. Cheng J, Sun CG, Chen Y, Dai YZ, Xu ZL, Sun GZ and Li XJ: Molecular analysis on chronic hepatitis B patients with low level HBsAg. Chin J Lab Med 32: 1128-1132, 2009.

7. Cheng J, Sun CG, Chen Y, Xu ZL, Wang GZ, Sun GZ and Li XJ: Analysis on clinical features and immunity in chronic hepatitis B virus infected patients with low-level HBsAg. Afr J Microbiol Res 4: 547-550, 2010.

8. Jeffery-Smith A, Hubb J, Oliver A and Tong CY: An apparent low level of hepatitis B surface antigen (HBsAg) in the presence of significant viral replication. J ClinVirol 77: 111-114, 2016.

9. Li JM: Attention to the confirmative tests of weak reactive samples should be paid in serological testing for infectious diseases. Chin J Lab Med 29: 577-580, 2006 (In Chinese).

10. Ozdil B, Cosar AM, Akkiz H, Sandikci MU and Kece C: Negative correlation between viral load and HBsAg levels in chronic HBV-infected patients. Arch Virol 154: 1451-1455, 2009.

11. De Gascun CF, Fraher M, Crean M, Connell J and Hall WW: The importance of being earnest: Following up a low level hepatitis B surface antigen (HBsAg) result. J ClinVirol 49: 79-81, 2010.
12. Tseng TC, Liu CJ, Yang HC, Su TH, Wang CC, Chen CL, Hsu CA, Kuo SF, Liu CH, Chen PJ, et al: Serum hepatitis B surface antigen levels help predict disease progression in patients with low hepatitis B virus loads. Hepatology 57: 441-450, 2013.

13. Martinot-Peignoux M, Lapalus M, Asselah T and Marcellin P: HBsAg quantification: Useful for monitoring natural history and treatment outcome. Liver Int 34: 97-107, 2014.

14. Huang G, Lau WY, Zhou WP, Shen F, Pan ZY, Yuan SX and Wu MC: Prediction of hepatocellular carcinoma recurrence in patients with low hepatitis B virus DNA levels and high preoperative hepatitis B surface antigen levels. JAMA Surg 149: 519-527, 2014.

15. Yang XH and Shi XF: Significance of HBsAg quantification in guiding clinical treatment of chronic hepatitis B. Zhonghua Gan Zang Bing Za Zhi 24: 317-320, 2016 (In Chinese).

16. Chen YC: Hepatitis B surface antigen (HBsAg) levels in the prediction of spontaneous HBsAg seroclearance. Hepatology 57: 1675,2013

17. Liu J, Yang HI, Lee MH, Jen CL, Batrla-Utermann R, Lu SN, Wang LY, You SL and Chen CJ: Serum levels of hepatitis B surface antigen and DNA can predict inactive carriers with low risk of disease progression. Hepatology 64: 381-389, 2016.

18. Liu L, Liu CY, Wang L and Liu YH: Analysis of pathological changes and related factors of liver tissue in patients with low level HBsAg. Zhonghua Gan Zang Bing Za Zhi 25: 526-528, 2017 (In Chinese).

19. Li MH, Xie Y, Zhang L, Lu Y, Shen G, Wu SL, Chang M, Mu CQ, Hu LP, Hua WH, et al: Hepatitis B surface antigen clearance in inactive hepatitis B surface antigen carriers treated with peginterferon alfa-2a. World J Hepatol 8: 637-643, 2016.

20. Seto WK, Wong DK, Fung J, Hung IF, Fong DY, Yuen JC, Tong T, Lai CL and Yuen MF: A large case-control study on the predictability of hepatitis B surface antigen levels three years before hepatitis B surface antigen seroclearance. Hepatology 56: 812-819, 2012.

21. Chook JB, Teo WL, Ngeow YF, Tee KK, Ng KP and Mohamed R: Universal primers for detection and sequencing of hepatitis $\mathrm{B}$ virus genomes across genotypes A to G. J Clin Microbiol 53: 1831-1835, 2015.

22. Hatazawa Y, Yano Y, Okada R, Tanahashi T, Hayashi H, Hirano H, Minami A, Kawano Y, Tanaka M, Fukumoto T, et al: Quasispecies variant of pre-S/S gene in HBV-related hepatocellular carcinoma with HBs antigen positive and occult infection. Infect Agent Cancer 13: 7, 2018.

23. Tamura K, Stecher G, Peterson D, Filipski A and Kumar S: MEGA6: Molecular evolutionary genetics analysis version 6.0. Mol Biol Evol 30: 2725-2729, 2013.

24. Liao H, Liu Y, Chen J, Ding W, Li X, Xu Z, Yang Y, Chen R, Si L, $\mathrm{Xu} \mathrm{X}$, et al: Characterization of hepatitis B virus (HBV) $\mathrm{preS} / \mathrm{S}$ gene mutations in blood donors with occult HBV infection in the baoji area of north china. Transfusion 57: 857-866, 2017.

25. Tong S and Revill P: Overview of hepatitis B viral replication and genetic variability. J Hepatol 64 (1 Suppl): S4-S16, 2016.

26. Norder H, Couroucé AM, Coursaget P, Echevarria JM, Lee SD, Mushahwar IK, Robertson BH, Locarnini S and Magnius LO: Genetic diversity of hepatitis B virus strains derived worldwide: Genotypes, subgenotypes, and HBsAg subtypes. Intervirology 47: 289-309, 2004.

27. Chinese Society of Hepatology, Chinese Medical Association; Chinese Society of Infectious Diseases, Chinese Medical Association, Hou JL and lai W: The guideline of prevention and treatment for chronic hepatitis B: A 2015 update. Zhonghua Gan Zang Bing Za Zhi 23: 888-905, 2015 (In Chinese).

28. WHO Guidelines Approved by the Guidelines Review Committee: Guidelines for the prevention-care and treatment of persons with chronic hepatitis B infection. Geneva: World Health Organization; 2015.

29. Kumar M, Sarin SK, Hissar S, Pande C, Sakhuja P, Sharma BC, Chauhan R and Bose S: Virologic and histologic features of chronic hepatitis B virus-infected asymptomatic patients with persistently normal ALT. Gastroenterology 134: 1376-1384, 2008.

30. Yin J, Xie J, Liu S, Zhang H, Han L, Lu W, Shen Q, Xu G, Dong H, Shen J, et al: Association between the various mutations in viral core promoter region to different stages of hepatitis B, ranging of asymptomatic carrier state to hepatocellular carcinoma. Am J Gastroenterol 106: 81-92, 2011.

31. Liang X, Bi S, Yang W, Wang L, Cui G, Cui F, Zhang Y, Liu J, Gong X, Chen Y, et al: Evaluation of the impact of hepatitis B vaccination among children born during 1992-2005 in china. J Infect Dis 200: 39-47, 2009. 
32. Mendy ME, McConkey SJ, Sande van der MA, Crozier S, Kaye S Jeffries D, Hall AJ and Whittle HC: Changes in viral load and HBsAg and $\mathrm{HBeAg}$ status with age in HBV chronic carriers in the gambia. Virol J 16: 49, 2008.

33. Zheng H, Wang FZ, Zhang GM, Miao N, Sun XJ and Cui FQ: The epidemiological characteristics of HBV susceptibility in 1-29 years old young people in china in 2006 and 2014: Based on the national sero-survey data analysis. Zhonghua Yu Fang Yi Xue Za Zhi 51: 581-586, 2017 (In Chinese; Abstract available in Chinese from the publisher).

34. Cui Y and Jia J: Update on epidemiology of hepatitis B and C in China. J Gastroenterol Hepatol 28: 7-10, 2013.

35. Goyal A and Murray JM: The impact of vaccination and antiviral therapy on hepatitis B and hepatitis D epidemiology. PLoS One 9: e110143, 2014.

36. Chen Y, Wu W, Li LJ, Lou B, Zhang J and Fan J: Comparison of the results for three automated immunoassay systems in determining serum HBV markers. Clin Chim Acta 372: 129-133, 2006.

37. Louisirirotchanakul S, Khupulsup K, Akraekthalin S, Chan KP, Saw S, Aw TC, Cho DH, Shin MG and Lim J: Comparison of the technical and clinical performance of the ElecsysHBsAg II assay with the architect, axSym, and advia centaur HBsAg screening assays. J Med Virol 82: 755-762, 2010.

38. Krawczyk A, Hintze C, Ackermann J, Goitowski B, Trippler M, Grüner N, Neumann-Fraune M, Verheyen J and Fiedler M: Clinical performance of the novel DiaSorin LIAISON((R)) XL murex: HBsAg quant, HCV-Ab, HIV-Ab/Ag assays. J Clin Virol 59: 44-49, 2014.

39. Zhong LH, Jiang YM, Lou GQ, Yu XL, Liu H, Guo JC, Zhu MF and Xun YH: The relationship between serum HBsAg levels and liver inflammation and fibrosis in patients with chronic hepatitis B. Zhonghua Shi Yan He Lin Chuang Bing Du Xue Za Zhi 27: 92-94, 2013 (In Chinese).
40. Liu J, Yang HI, Lee MH, Lu SN, Jen CL, Wang LY, You SL, Iloeje UH and Chen CJ; REVEAL-HBV Study Group: Incidence and determinants of spontaneous hepatitis B surface antigen seroclearance: A community-based follow-up study. Gastroenterology 139: 474-482, 2010.

41. Karagoz E, Tanoglu A and Turhan V: Correlation between hepatitis B surface antigen titers and HBV DNA levels: What about the parameters affecting this correlation? Saudi J Gastroenterol 20: 74, 2014.

42. Karagoz E, Selek MB, Tanoglu A, Hatipoglu M, Ulcay A and Turhan V: Comparison of the ElecsysHBsAg II assay and the architect assay for quantification of hepatitis B surface antigen in patients with chronic hepatitis B. Infez Med 24: 287-292, 2016.

43. Karra VK, Chowdhury SJ, Ruttala R, Polipalli SK and Kar P: Clinical significance of quantitative HBsAgtitres and its correlation with HBV DNA levels in the natural history of hepatitis B virus infection. J Clin Exp Hepatol 6: 209-215, 2016.

44. Wang T, Dai Y, Lu W, Zhou H, Chen Y, Xu X, Sun C and Cheng J: An epidemiological survey of $\mathrm{HBV}$ infection and low-level HBsAg in military camps in eastern China. Medicine (Baltimore) 97: e12201, 2018.

45. Zeng DW, Liu YR, Dong J, Zhu YY, Li YB, Chen J, Zheng Q and Jiang JJ: Serum HBsAg and HBeAg levels are associated with liver pathological stages in the immune clearance phase of hepatitis B virus chronic infection. Mol Med Rep 11: 3465-3472, 2015.

(i) $(5)$ This work is licensed under a Creative Commons Attribution-NonCommercial-NoDerivatives 4.0 International (CC BY-NC-ND 4.0) License. 